\title{
AGE AT FIRST CONCEPTION OF HIGH YIELDING COWS
}

\section{Ž. Novaković, Lj. Sretenović, S. Aleksić, M. M. Petrović, V. Pantelić, D. Ostojić-Andrić}

Institute for Animal Husbandry, Belgrade-Zemun, Republic of Serbia Corresponding author: zeljko.novakovic013@gmail.com

Original scientific paper

Abstract: Black and White low land dairy cattle have very pronounced ability for high production of milk. Fertility is the major trait of cattle and key factor in successful milk production. Fertility traits have pronounced variability and low heritability value. Fertility is regularly limiting factor in attempts to increase the milk yield. Age of dairy cattle at first conception is one of the major reproduction properties. Age of calves at first calving depends mainly on age at first conception. Previous researches have indicated what would be the optimum age at first conception of Black and White heifers. Age at first conception is determined by the date of birth and date of first conception. Knowledge of the strength of the environment factors on age at first conception in high yielding cows is important from the aspect of their inclusion into the model. According to the significance of individual systematic factors, their objective assessment was carried out for the purpose of accurate evaluation of obtained results. Objective of this paper is to study the age at first conception of high yielding Black and white cows through major systematic influences, by applying adequate methodology. Cows comprising the studied sample $(\mathrm{n}=331)$ belong to European type of Black and White dairy cattle in final stage of improving of this breed with Holstein-Friesian breed. Average age of dairy cattle at first conception was $491.19 \pm 9.36$ days or $16.15 \pm 0.31$ months. According to cows' the values were following: 479.31 days ( $>$ $73 \% \mathrm{HF}), 486.12$ days $(58-73 \% \mathrm{HF})$ and 508.14 days $(<58 \% \mathrm{HF})$.

Key words: Holstein-Friesian cows, fertility, influence factors

\section{Introduction}

Black and White low land dairy cattle have high genetic potential for milk production and take very important position in our dairy cattle breeding. They have high share in total milk production, in spite of relatively los share in total cattle population. Production conditions often are not adequate to the requirements of this 
breed. Consequently, various fertility problems occur. Fertility is often limiting factor in attempts to increase the milk yield.

Introduction of Holstein-Friesian genes (HF) within the program of improvement of European Black and White dairy cattle resulted in increase of milk yield and tendency towards decrease in fertility. Selection for high milk yield had significant impact on growth and development of HF heifers which had consequences on production of milk, primarily, but later also on health, fertility and longevity of animals (Coffey et al., 2006).

Fertility traits have considerable economic significance exhibited through normal flow of production cycle. Reproduction traits show high variability under the impact of complex factors of the environment (Lucy, 2001).

Sexual maturity is age when heifer for the first time shows signs of oestrus which subsequently and continuously is displayed in regular cycles. Time of sexual maturity depends not only on the age but is also result of the effect of numerous genetic (process of sexual maturation, display of sexual maturity) and environment factors (nutrition, climate, rearing, housing, care, etc.). After reaching the sexual maturity, animals require adequate period for further body development in which necessary breeding maturity of animal will occur. Beginning of the breeding maturity is variable and depends mainly on the body weight of animals (Smiljaković et al., 2007). Age at first conception includes the period from the birth of heifer to first insemination at the age when animal has reached breeding maturity enabling it normal gravidity. Age when animal reaches sexual and breeding maturity has for long time been in the centre of attention of expert and scientific public in regard to the possibility for shortening of the generation interval. Age at first calving is important factor influencing the yield and composition of milk (Pirlo et al., 2000).

Age at first conception is one of the most important fertility properties in dairy cattle. It has direct impact on age at first calving since duration of gravidity has physiologically constant value. Many scientific studies have established the positive relation between the body mass at first calving and milk yield in the first lactation. This relation is important basis for defining of levels of body development and age of heifers at first conception/calving. Rearing of heifers significantly participates in total costs/expenses of the cattle farm. After cost of feeding, they come at the second place in their value within the annual operational costs. One of the ways to reduce the cost is to decrease the period of rearing of heifers before their fist conception/calving. In case of heifers of high yielding breeds, sexual maturity is reached at the age of 9-11 months and average body mass of 250-280 kg (Sejrsen and Purp, 1997). Most of recommendations refer to first insemination of heifers at the age of 14 to 15 months and body mass of $\geq 350$ $\mathrm{kg}$, in order to achieve age at calving of 24 months (Antov et al., 1998).

In the research by Romčević et al., (1990) average age of heifers at calving of 781.33 days or 25.69 months was established, in tie system, and in loose housing system - 812.49 days or 26.71 months. Milić et al. (1993) stated for HF cows $(\mathrm{n}=703)$ average age at first calving in two housing systems (tie and loose) in 
average was 787 days or 25.87 months. Skalicki et al. (1991), within their study of phenotypic characteristics of reproduction traits of Black and White cattle with different share of HF genes (ranges: $20-40 \%$; 40.1-60\%; 60.1-80\%), established average age of heifers at first conception of 515.08 days (var. from 497.25-540.81 days). Petrović et al. (2007) in the study of the phenotypic and genetic parameters of reproductive traits of Black and White cows with different share of HF genes (I$50 \%$, II- $75 \%$ and III-100\%), established average age at first conception of 493.50 days.

Optimal age of heifers at first calving for HF breed and from the aspect of maximum economical gain, should be 23 to 24 months. In the function of maximum use of genetic potential for production of milk and decrease of costs of rearing, recommendation is that average age of HF heifers at first calving be $\leq 24$ months and body mass of $>560 \mathrm{~kg}$ after calving with 24 months (Heinrichs, 1993; Tozer and Heinrichs, 2001). Heifer should have adequate body development at the age of 22 to 24 months in order to ensure acceptable level of milk yield in the first lactation and reduce the number of difficult calvings (Hoffman and Funk, 1992; Van Amburgh et al., 1994). First calving at the age of $<23$ months caused lower yields of milk and milk components in the first lactation and more reproductive problems. However, increase of age at fist calving to $>24.5$ months didn't improve the milk yield, reproduction or health of first calving cows (Ettema and Santos 2004).

Previous studies indicate the acceptable age at first conception/calving of Black and White heifers. Age at first conception is determined within defined time limits. Bottom limit is date of birth, and top limit date of conception. Knowledge of the strength of environment factors on age at first conception in high yielding cows is important from the aspect of their inclusion in the model. In accordance to the importance of individual systematic factors, they were assessed objectively in this study for the purpose of accurate evaluation of obtained results.

\section{Materials and Methods}

Study of the fertility was carried out on high yielding Black and White cows. Studied animals belonged to European type of Black and White dairy cattle which were in the final stage of improvement using the HF breed. Studied sample of cows $(\mathrm{N}=331)$ were in same housing conditions (tie system), nutrition (complete mixture), care and exploitation. Within fertility traits, age at first conception was studied and quantitatively presented in days.

Analysis of the effect of certain systematic factors was done by applying the Least square method (Harvey, 1987) and of this method was expressed in the possibility of simultaneous determination of several effects on studied traits. Mathematical-statistical analysis of data in samples for studied fertility trait was done by using following linear models: 
Distribution according to classes:

\begin{tabular}{|c|c|c|c|}
\hline Class of HF genes & $<58 \%$ & $58-73 \%$ & $>73 \%$ \\
\hline $\mathrm{n}$ & 83 & 125 & 123 \\
\hline
\end{tabular}

\begin{tabular}{|c|c|c|c|c|c|c|c|c|c|c|}
\hline Calving year & 86 & 87 & 88 & 89 & 90 & 91 & 92 & 93 & 94 & 95 \\
\hline $\mathrm{n}$ & 5 & 16 & 30 & 56 & 67 & 34 & 48 & 29 & 31 & 15 \\
\hline
\end{tabular}

\begin{tabular}{|c|c|c|c|c|}
\hline Calving season & 1 & 2 & 3 & 4 \\
\hline $\mathrm{n}$ & 79 & 63 & 78 & 111 \\
\hline
\end{tabular}

Applied models:

a. Mixed:

$\mathrm{Y}_{\mathrm{ijk} l m}=\mu+\mathrm{O}_{\mathrm{i}}+\mathrm{HF}_{\mathrm{j}}+\mathrm{G}_{\mathrm{k}}+\mathrm{S}_{1}+\mathrm{e}_{\mathrm{ijklm}}$

b. Fixed (to obtain solutions for bull sires):

$\mathrm{Y}_{\mathrm{ijklm}}=\mu+\mathrm{O}_{\mathrm{i}}+\mathrm{HF}_{\mathrm{j}}+\mathrm{G}_{\mathrm{k}}+\mathrm{S}_{1}+\mathrm{e}_{\mathrm{ijk} k \mathrm{~m}}$

where:

$\mathrm{Y}_{\mathrm{ijklm}}=$ result of $\mathrm{m}$ cow, daughter of $\mathrm{i}$ bull, which belongs to $\mathrm{j}$ group according to share of HF genes, calved in $\mathrm{k}$ year and 1 season

$\mu \quad=$ general average

$\mathrm{O}_{\mathrm{i}} \quad=$ in mixed model random, and in fixed model fixed effect of $\mathrm{i}$ bull sire

$\mathrm{HF}_{\mathrm{j}}=$ fixed effect of $\mathrm{j}$ group of $\mathrm{HF}$ genes

$\mathrm{G}_{\mathrm{k}} \quad$ = fixed effect of $\mathrm{k}$ calving year

$\mathrm{S}_{1} \quad$ = fixed effect of 1 calving season

$\mathrm{e}_{\mathrm{ijklm}}=$ random error

\section{Results and Discussion}

Age of cows at first calving mainly depends on age of cows at first conception, and age at first conception depends on genotype, nutrition, housing system, care, etc., and both fertility indicators have shown high phenotypic correlation. Reason for this is duration of gravidity contained in the age at first calving, and at the same time most often shows low phenotypic variability and represents biological constant mainly determined by the breed's genetic basis. 
Table 1. Deviation (c ) and deviation errors (Sc) from the general average ( $\mu$ ) and mean value (lsm) and mean value errors (Slsm) of the least squares of studied effects on age at first conception (days)

\begin{tabular}{|c|c|c|c|c|c|}
\hline Effects & $\mathrm{N}$ & C & $\mathrm{Sc}$ & 1sm & Slsm \\
\hline \multicolumn{6}{|c|}{ Total } \\
\hline M & 331 & 491.19 & 9.36 & 491.19 & 9.36 \\
\hline \multicolumn{6}{|c|}{ Class of HF genes of cow $\left(d f_{1}=2, d f_{2}=299, f_{-e x p}=1.699 n s\right)$} \\
\hline$<58 \%$ & 83 & 16.95 & 9.32 & 508.14 & 13.65 \\
\hline $58-73 \%$ & 125 & -5.07 & 7.28 & 486.12 & 11.71 \\
\hline$>73 \%$ & 123 & -11.88 & 8.30 & 479.31 & 12.18 \\
\hline \multicolumn{6}{|c|}{ Bull sires $\left(d f_{1}=17, d f_{2}=299, f_{-\exp }=1.683 *\right)$} \\
\hline 23 & 42 & 48.50 & 19.68 & 539.95 & 19.39 \\
\hline 28 & 20 & -46.36 & 21.76 & 445.08 & 22.72 \\
\hline 33 & 3 & 106.75 & 53.43 & 598.20 & 55.59 \\
\hline 35 & 29 & -56.87 & 23.09 & 434.58 & 23.32 \\
\hline 36 & 45 & -18.16 & 17.99 & 473.28 & 18.19 \\
\hline 38 & 11 & -54.42 & 31.93 & 437.03 & 33.36 \\
\hline 270 & 22 & 109.79 & 27.93 & 601.24 & 28.38 \\
\hline 283 & 5 & 127.82 & 46.87 & 619.27 & 47.74 \\
\hline 293 & 8 & -103.72 & 45.24 & 387.73 & 46.02 \\
\hline 337 & 7 & -72.77 & 37.60 & 418.68 & 39.19 \\
\hline 762 & 21 & 57.26 & 25.99 & 548.71 & 25.73 \\
\hline 795 & 6 & 13.14 & 45.95 & 504.59 & 45.22 \\
\hline 816 & 33 & 22.07 & 18.08 & 513.52 & 17.65 \\
\hline 879 & 7 & -40.93 & 34.27 & 450.52 & 36.03 \\
\hline 927 & 31 & -22.72 & 18.22 & 468.73 & 18.61 \\
\hline 1040 & 19 & -40.90 & 26.07 & 451.36 & 27.07 \\
\hline 1304 & 15 & -27.28 & 24.59 & 464.17 & 25.45 \\
\hline 5368 & 7 & -2.02 & 33.32 & 489.43 & 35.06 \\
\hline \multicolumn{6}{|c|}{ Calving year $\left(d f_{l}=9, \quad d f_{2}=299, f_{-e x p}=3.316^{* *}\right)$} \\
\hline 86 & 5 & -62.33 & 44.71 & 428.86 & 47.89 \\
\hline 87 & 16 & -120.18 & 29.31 & 371.01 & 30.90 \\
\hline 88 & 30 & -101.79 & 27.01 & 389.40 & 28.14 \\
\hline 89 & 56 & -44.01 & 18.92 & 447.17 & 19.87 \\
\hline 90 & 67 & 19.02 & 14.59 & 510.20 & 15.81 \\
\hline 91 & 34 & 19.27 & 18.04 & 510.46 & 19.59 \\
\hline 92 & 48 & 66.14 & 19.39 & 557.33 & 20.67 \\
\hline 93 & 29 & 40.08 & 20.88 & 531.26 & 22.43 \\
\hline 94 & 31 & 64.95 & 25.85 & 556.14 & 27.09 \\
\hline 95 & 15 & 118.84 & 36.47 & 610.03 & 37.93 \\
\hline \multicolumn{6}{|c|}{ Calving season $\left(d f_{1}=3, d f_{2}=299, f_{-e x p}=2.949 *\right)$} \\
\hline I & 79 & -23.59 & 8.85 & 467.60 & 12.86 \\
\hline II & 63 & -2.97 & 9.23 & 488.21 & 13.76 \\
\hline III & 78 & 15.52 & 8.78 & 506.70 & 12.81 \\
\hline IV & 111 & 11.05 & 8.00 & 502.23 & 11.69 \\
\hline
\end{tabular}

Average age at first conception observed on 331 animals was at the level of $491 \pm 9.36$ days (Table 1). Observed according to cows' genotypes, mean values 
were 479.31 days $(>73 \% \mathrm{HF}), 486.12$ days $(58-73 \% \mathrm{HF})$ and 508.14 days $(<$ $58 \% \mathrm{HF})$.

Similar results relating to age at first conception/calving were obtained by Romčević et al. (1990), Skalicki (1991), Milić et al. (1993), Petrović et al., (2007), whereas recommendations and results stated by Hoffman and Funk (1992), Heinrichs (1993), Van Amburgh et al. (1994), Tozer and Heinrichs (2001), Ettema and Santos (2004) in regard to age at first conception/calving are lower compared to results obtained in the present study.

Considering that heifers of high yielding dairy breeds reach sexual maturity at the age of 9 to 11 months and body mass of 250-280 kg (Sejrsen and Purp, 1997), for the purpose of reduction of rearing costs it is preferable that rearing period to first conception is reduced to 14 to 15 months so that first calving could be realized at the age of 24 months (Antov et al., 1998).

Of studied systematic factors, significant effect on differences within the age at first conception $(\mathrm{p} \leq 0.05)$ was determined for bull sires, and class of HF genes had no significant effect ( $p>0.05)$, calving year displayed highly significant effect $(p \leq 0.01)$, and calving season significant effect $(p \leq 0.05)$.

\section{Conclusion}

Average age of animals at first conception was $491.19 \pm 9.36$ days or $16.15 \pm 0.31$ months. According to cows' genotypes, mean values were 479.31 days ( $>73 \% \mathrm{HF}), 486.12$ days $(58-73 \% \mathrm{HF})$ and 508.14 days $(<58 \% \mathrm{HF})$.

The study clearly indicates that within the framework of studied systematic factors on established differences in age at first conception significant effect $(p \leq 0.05)$ was determined for bull sires, and class of HF genes had no significant effect $(p>0.05)$, calving year displayed highly significant effect $(p \leq 0.01)$, and calving season significant effect $(\mathrm{p} \leq 0.05)$.

Age of heifers at first conception has impact on milk production in the first lactation, but also on life long milk production. Insemination of heifers in optimal time is one of the ways to lower the costs and increase the quantity of produced milk.

\section{Acknowledgment}

Research was financed by the Ministry of Education and Science, Republic of Serbia, project TR-31053. 


\title{
Uzrast visokomlečnih krava kod prve oplodnje
}

\author{
Ž. Novaković, Lj. Sretenović, S. Aleksić, M. M. Petrović, V. Pantelić, D. Ostojić- \\ Andrić
}

\section{Rezime}

Osobine plodnosti imaju izuzetno veliki ekonomski značaj koji se ispoljava kroz normalan tok proizvodnog ciklusa. Jedna od njihovih vrlo važnih specifičnosti je veoma izražena varijabilnost i niska naslednost. Uzrast grla kod prve oplodnje/teljenja je važna osobina plodnosti goveda.

Crno-bela nizijska goveda imaju izraženu genetsku sposobnost za visoku proizvodnju mleka. Visokoproizvodne krave crno-bele rase izložene su tokom produktivnog veka velikom broju složenih uticaja. Uslovi proizvodnje vrlo često nisu u saglasnosti sa visokim potrebama ove rase. Problemi u reprodukciji često predstavljaju ograničavajući faktor za povećanje proizvodnje mleka.

Unošenjem gena holštajn-frizijske rase $u$ okviru programa oplemenjivanja evropskih crno-belih goveda došlo je do tendencije povećanja prinosa mleka i smanjenja plodnosti. Dosadašnja istraživanja ukazuju na prihvatljiv uzrast pri prvoj oplodnji kod junica crno-bele rase.

Poznavanje jačine uticaja sredine na uzrast pri prvoj oplodnji kod visokomlečnih krava važno zbog njihovog uključivanja u model. U skladu sa pojedinačnim značajem sistematskih faktora, obavljena je njihova objektivna procena radi što tačnijeg vrednovanja ostvarenih rezultata.

Cilj ovog rada je bio da se primenom odgovarajuće metodologije ispita uzrast kod prve oplodnje visokomlečnih crno-belih krava preko najvažnijih sistematskih uticaja. Krave u okviru ispitanog uzorka $(n=331)$ pripadaju evropskim crno-belim nizijskim govedima u završnoj fazi oplemenjivanja holštajn-frizijskom rasom.

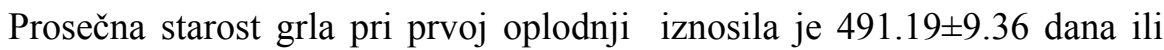
$16.15 \pm 0.31$ meseci. Posmatrano po genotipovima krava iznosio je 479.31 dana (> $73 \% \mathrm{HF}), 486.12$ dana $(58-73 \% \mathrm{HF})$ i 508.14 dana $(<58 \% \mathrm{HF})$. Na utvrđene razlike u pogledu uzrasta pri prvoj oplodnji značajan uticaj $(\mathrm{p} \leq 0.05)$ pokazali su bikoviočevi, klasa HF gena krava nije imala značajan uticaj ( $p>0.05)$, godina teljenja pokazala je visoko značajan uticaj $(\mathrm{p} \leq 0.01)$, dok je sezona teljenja ispoljila značajan uticaj $(\mathrm{p} \leq 0.05)$.

\section{References}

ANTOV G., ČOBIĆ T., ANTOV A., LATINOVIĆ D., PLAVŠIĆ M. (1998): Uticaj nivoa ishrane i veličine tela junica na prinos mleka mleka u prvoj laktaciji. Savremena poljoprivreda, 1-2, 169-174. 
COFFEY M.P., HICKEY J., BROTHERSTONE S. (2006): Genetic aspects of growth of holstein-friesian dairy cows from birth to maturity. J. Dairy Sci., 89, 322-329.

ETTEMA J.F., SANTOS J.E.P. (2004): Impact of age at calving on lactation, reproduction, health, and income in first-parity holsteins on commercial farms. J. Dairy Sci., 87, 2730-2742.

HARVEY W.R. (1987): Mixed model least squares and maximum likelihood computer program. User's Guide for LSMLMW and MIX MDL.

HEINRICHS A.J. (1993): Raising dairy replacements to meet the needs of the 21st century. J. Dairy Sci., 76, 3179-3187.

HOFFMAN P.C., FUNK D.A. (1992): Applied Dynamics of Dairy Replacement Growth and Management. J. Dairy Sci., 75, 2504.

LUCY M.C. (2001): ADSA Foundation Scholar Award Reproductive Loss in High-Producing Dairy Cattle: Where Will It End? J. Dairy Sci., 84, 1277-1293.

MILIĆ M., NENADOVIĆ M., ŽOLT N., SATARIĆ D. (1993): Uticaj sistema držanja krava na proizvodnju mleka u prvoj standardnoj laktaciji. Savremena poljoprivreda, 1-2, 49-52.

PETROVIĆ M.M., ALEKSIĆ S., SMILJAKOVIĆ T., PANTELIĆ V., OSTOJIĆANDRIĆ D. (2007): Phenotypic and genetic parameters of reproductive traits of black and white cows with different share of HF genes. Biotechnology in Animal Husbandry, 23, 5-6, 193-199.

PIRLO G., MIGLIOR F., SPERONI M. (2000): Effect of age at first calving on production traits and on difference betweenmilk yield returns and rearing costs in Italian Holsteins. J. Dairy Sci., 83, 603-608.

ROMČEVIĆ LJ., STOJIĆ P., KATIĆ M., PEROVIĆ A., TEPAVAC M. (1990): Uticaj starosti u vreme prvog teljenja na proizvodne performanse krava u dva sistema držanja. IX Seminar inovacije u stočarstvu, Poljoprivredni fakultet, Univerzitet u Beogradu.

SEJRSEN K., PURP S. (1997): Influence of pre-pubertal feeding level on milk yield potential of dairy heifers: a review. J Anim. Sci., 75, 828-835.

SKALICKI Z., LATINOVIĆ D., LAZAREVIĆ LJ., STOJIĆ P. (1991): Fenotipske karakteristike reproduktivnih osobina crno-belih goveda sa različitom proporcijom gena holštajn-frizijske rase. Zbornik radova Poljoprivrednog fakulteta, radovi sa VII naučnog skupa zootehničara Jugoslavije, Beograd 2, 33.

SMILJAKOVIĆ T., PETROVIĆ M.M., POLEKSIĆ V., ALM H., PETROVIĆ M.P., RADOVIĆ Č., PEJČIĆ S. (2007): Anatomsko-fiziološke osnove reprodukcije domaćih životinja. Biotechnology in Animal Husbandry, 23, 1-2, 105-112.

TOZER P.R., HEINRICHS A.J. (2001): What affects the costs of raising replacement dairy heifers: A multiple-component analysis? J. Dairy Sci., 84, 1836-1844. VAN AMBURGH M.E., GALTON D.M., FOX D.G., BAUMAN D.E., CHASE L.E., ERB H.N., EVERETT R.W. (1994): Effect of pre-pubertal growth rate in Holstein heifers on first lactation milk yield. J. Dairy Sci., 77, Suppl. 1, 185. (Abstr.). 